Revue d'études américaines. American Studies Journal

2 | 2011

Sport et société / Animals and the American

Imagination

\title{
Jack Kerouac's Ecopoetics in The Dharma Bums and Desolation Angels : Domesticity, Wilderness and Masculine Fantasies of Animality
}

Pierre-Antoine Pellerin

\section{OpenEdition}

\section{Journals}

Electronic version

URL: https://journals.openedition.org/transatlantica/5560

DOI: 10.4000/transatlantica.5560

ISSN: 1765-2766

Publisher

Association française d'Etudes Américaines (AFEA)

Electronic reference

Pierre-Antoine Pellerin, " Jack Kerouac's Ecopoetics in The Dharma Bums and Desolation Angels :

Domesticity, Wilderness and Masculine Fantasies of Animality", Transatlantica [Online], 2 | 2011 , Online since 15 May 2012, connection on 31 January 2023. URL: http://journals.openedition.org/ transatlantica/5560 ; DOI: https://doi.org/10.4000/transatlantica.5560

This text was automatically generated on 31 January 2023

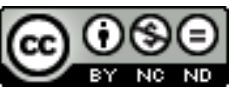

Creative Commons - Attribution-NonCommercial-NoDerivatives 4.0 International - CC BY-NC-ND 4.0 https://creativecommons.org/licenses/by-nc-nd/4.0/ 


\title{
Jack Kerouac's Ecopoetics in The Dharma Bums and Desolation Angels : Domesticity, Wilderness and Masculine Fantasies of Animality
}

\author{
Pierre-Antoine Pellerin
}

1 Reflecting upon the founding myths of the American nation, one cannot help but consider the importance and significance of the notion of wilderness. From the biblical idea of a moral and physical wasteland to be conquered in the accounts written by early pioneers to the environmentalist movement's call to preserve it as a fragile and valuable ecosystem, the wilderness has been the locus of changing and competing definitions of American identity. ${ }^{1}$ Feminist critics have also shown how the wilderness is a profoundly gendered notion and has heavily influenced-and is influenced byconstructions of femininity and masculinity. ${ }^{2}$ Indeed, since it was first explored and conquered by trappers and explorers in the early $19^{\text {th }}$ century, the Wild West has been imagined as an exclusively masculine space from which women and children were absent and where men could build and prove their manliness. Virgin lands and unspoiled nature peopled only by wild animals and wild Indians offered American men a series of tests and challenges that required mental and physical strength. Whereas women were bound to the domestic space of home and the social function of nurture, men were associated with the adventurous life on the Frontier. In this liminal space which Frederick Jackson Turner termed the meeting point between savagery and civilization" (Turner, 32-33), men underwent "rapid and effective Americanization" and could build up a sense of primitive manliness defined in terms of animality. American fiction provides evidence of a long-lasting relationship between men and wild animals in the American imagination, most notably through what David Leverenz calls the beast-man motif. ${ }^{3}$ Stripped of the garments of civilization and reduced to the bare essentials of life in the wilderness, male characters who called no man (nor woman for that matter) master could reclaim a lost animality: "To be aggressive, rebellious, enraged, uncivilized: this is what the frontier could do for the European 
clones on the East Coast, still in thrall to a foreign tyranny of manners" (Leverenz, 32). Interestingly enough, American authors often described their experience of the land in essentially feminine terms, projecting maternal or sexual fantasies onto the wilderness that surrounded their male protagonists.

In the 1950s however, the feeling that such a space was rapidly disappearing started to gain vivid attention from journalists, writers and intellectuals alike. American men's favorite playground was feared to be vanishing and, with it, the manly ideal on which the nation had been built, so much so that Life Magazine labeled 1954 the year of "the domestication of the American male." Arthur M. Schlesinger, one of the most influential intellectuals and historians of the times, echoed this concern in an essay entitled "The Crisis of American Masculinity" (1958) in which he deplored the extinction of this primitive species of manly heroes in American literature:

For a long time, [the American male] seemed utterly confident in his manhood, sure of his masculine role in society, easy and definite in his sense of sexual identity. The frontiersmen of James Fenimore Cooper, for example, never had any concern about masculinity; they were men, and it did not occur to them to think twice about it. Even well into the $20^{\text {th }}$ century, the heroes of Dreiser, of Fitzgerald, of Hemingway remain men. But one begins to detect a new theme emerging in some of these authors, especially in Hemingway: the theme of the male hero increasingly preoccupied with proving his virility to himself. And by mid-century, the male role had plainly lost its rugged clarity of outline. (Schlesinger, 292)

For Schlesinger, this new literary paradigm was the result of a transformation in gender roles both at home and in society at large, and the symptom of men's troubled identity in the midst of America's growing feminization:

The roles of male and female are increasingly merged in the American household. The American man is found as never before as a substitute for wife and motherchanging diapers, washing dishes, cooking meals, and performing a whole series of what once were considered female duties. The American woman meanwhile takes over more and more of the big decisions, controlling them indirectly when she cannot do so directly. Outside the home, one sees a similar blurring of function. [...] Women seem an expanding, aggressive force, seizing new domains like a conquering army, while men, more and more on the defensive, are hardly able to hold their own and gratefully accept assignments from their new rulers. (Schlesinger, 292-93)

In other words, the wild beast-men of bygone days had been tamed and domesticated into companion species, contained at home by their female master who had ruined their animal instincts.

It is in that context of perceived collective emasculation that a new genre of pulp fiction arose to prominence in the early 1950s, the "man VS wild animal" story featured in men's adventure magazines. ${ }^{5}$ Aimed at a readership of men exclusively, they staged "real men" in "real action," "true stories" about "true men" who were opposed to the wildest animals on earth. The hairy-chested outdoorsmen portrayed in those compensatory fantasies of virility travelled the entire world in quest for danger and for the excitement of their many male readers, next to reports about various sex-related topics. ${ }^{6}$ Those stories displayed an astonishing bestiary of dangerous animals whose savagery was the central focus of the stories they featured: alligators, crocodiles, spiders, scorpions, tigers, lions, jaguars, panthers, elephants, rhinoceros, giants squids, giant ants, giant crabs, giant turtles, sharks, octopuses, snakes, hawks, wolves, wild cats, buffalos, piranhas, gorillas, apes, komodo dragons or vultures were set as 
antagonists in violent, bloody confrontations that served as masculinity tests in which those men put their life at risk. When animals went missing, pygmies, "leopard men," savages, or members of some primitive tribe, depicted as bloodthirsty monsters, took up the role and offered mostly white suburban male readers a temporary flight from their self-perceived domestication through racial and sexual fantasies of animality.

Throughout his autobiographical cycle of fourteen novels, which he entitled "The Legend of Duluoz," Jack Kerouac also tried to present himself, his narrator and his protagonists as archetypes of American masculinity who fought against their domestication by American women. He often expressed a desire to belong to this tradition of manly writers who went into the wild and struggled with natural dangers, men like Ernest Hemingway or Jack London whom he idealized as real men and real writers. Whether it be in the Sierra Nevada in 1955, in The Dharma Bums (1958),or in the Northern Cascades in 1956, in Desolation Angels (written in 1956 and 1961, published in 1965), Kerouac's alter ego and first-person narrator engages in an escapist fantasy into the animal realm where he can regain a sense of authentic masculine identity, away from the feminizing effects of domesticity and civilization. ${ }^{78}$ Yet, in his novels, dangerous wild animals are almost never to be found and the long-awaited encounter with bears or wolves does not occur, forcing the narrator to reconfigure the relationship between animality and masculinity. Taking men's adventure magazines as the dominant norm in this regard, this paper aims at showing how Kerouac's representation of masculinity strongly diverges from the "man VS wild animal" story, notably thanks to the complex and compassionate representation of wild animals. While Kerouac and his fellow Beats appear first and foremost as a group of writers dealing mostly with city life and road adventures, recent studies have examined the importance of the theme of nature and wilderness in their writings. ${ }^{9}$ Yet, the centrality of animals and animality in Kerouac's fiction has remained largely invisible. ${ }^{10}$ Contrary to most Beat scholarship that tends to regard Kerouac as an urban, jazz-influenced, egotistic author, this paper aims at showing how notions of ecology, environment and hospitality toward animals are critical to understanding Kerouac's poetics.

\section{Into the Wild: Male Domestication and Kerouac's Proud-Animal}

7 In an early essay written when he was still a young man, Kerouac voices his fear of men's domestication by emasculating wives and mothers and describes how men have lost their true animal nature, their primitive wildness, and have been harnessed into becoming docile and submissive pets:

Man in the Beginning was a proud animal who went out and killed his game and dragged his woman to a cave and ate with her, and performed the sticky art of love on her, and slept with her, and awoke in the morning, cold and dreary in the prehistoric pink of primeval dawn. Today, he shells out five bucks for some grocery food, takes it home to a haughty, commandeering wife, meekly performs the sticky art of love on her at night in a soft willowy bed, and wakes up in the cold and dismal pink of civilized dawn. The difference? Man is now a civilized animal, but he is no longer a proud animal. ( 'A A Noble Experiment', Subject: What will my books be about this summer?", n.p., italics added)

8 For Kerouac, as for many men at the time, not only was wilderness threatened by (sub)urbanization, industrialization and modernization, but men themselves were 
thought to have been tamed and domesticated. They had become captives, chained as they were to their home through their role as family men and softened by the civilizing effects of a feminized culture. The metaphor of domestication implied that men were (wild) animals by nature and that civilization had spoiled and repressed men's "natural" (and sexual) instincts.

This wild/domestic dichotomy structures Kerouac's entire cycle of novels and accounts for the gendered separation between public and private spheres. In Visions of Cody (written in 1951)already, Kerouac reviles the domestic, feminine space of home (and the roles of husband, father and breadwinner), and condemns the wolfish consumerism of "wives and women right now, with feminine purposes, with that ravenous womany glee trotting around town buying boxes of soap, Jell-O, floor wax, Dutch Cleanser," eventually expressing his fear of "men enslaved to cunts" (Kerouac, 1993b, 67). Though it represents a first way out in On the Road (1957), the road itself seems to have become feminized by the end of the decade. In Big Sur (1962), Kerouac draws a satirical portrait of men's domestication as he is waiting for a ride back to San Francisco while innumerable station wagons pass by without stopping: "the husband is in the driver's seat with a long ridiculous vacationist hat with a long baseball visor making him look witless and idiot-Beside him sits wifey, the boss of America, wearing dark glasses and sneering, even if he wanted to pick me up or anybody up she wouldn't let him" (Kerouac, 1962, 44). For Kerouac, men had been tamed by women, whom he presented as civilizing agents who had robbed men of their wild nature and subdued their primitive energy. In order to revitalize American masculinity, he thus set out to reopen in the American imagination and in literary fiction a homosocial space where men could become the wild animals they once were. Thoroughly influenced by Oswald Spengler's The Decline of the West, Kerouac tried to give birth to what the German philosopher called the fellah type, a "primeval man" characterized as a "ranging animal, a being whose waking-consciousness restlessly feels its way through life, all microcosm, under no servitude of place or home, keen and anxious in its senses" (Spengler, 89). In Desolation Angels and The Dharma Bums, it is this very animal that Kerouac's narrator seeks out to become in his flight into the wild.

In The Dharma Bums, the narrator Ray Smith (Kerouac's fictional persona) and his friend Japhy Ryder (based on real-life poet and environmental activist Gary Snyder whom he had met in the Fall of 1955) thus decide to leave modern civilization behind to follow the footsteps of Jack London and John Muir, disappearing into the backwoods of the Sierra Nevada. ${ }^{11}$ They pursue a line of flight into a world of men without women, away from perceived domestication and the symbolic death it implies-“"Pretty girls make graves' was my saying then," Kerouac's narrator flaunts (DB, 21). Suburban domestic culture, essentially defined in terms of femininity, implies for Ray a world of "work, produce, consume, work, produce, consume" which results in the "middle-class nonidentity" criticized through the growth and morphology of suburban residential zones and their "rows of well-to-do houses with lawns and TV sets in each living room, with everybody looking at the same thing and thinking the same thing at the same time, while the Japhies of this world go prowling the wilderness to find the ecstasy of the stars" (DB, 28). Living a secluded life, a vie de sauvage afar from the feminizing effects of civilization, allows the protagonists to enter the animal realm and to reverse to their wild natural state, recapturing a lost animality in a return journey to a Golden Age of masculinity, a time when men still were "proud animals." 
11 Japhy Ryder, "the big hero of the West Coast" (DB, 23), exemplifies this freedom from domesticity and will thus serve as the narrator's mentor in this initiation to his new life in the woods. Ray Smith compares him to the wildest male characters in American popular fiction, "real grave like Buck Jones, eyes to the distant horizons, like Natty Bumppo, cautioning me about snapping twigs" (43). Japhy, the narrator informs us, is "from the beginning a woods boy, an axman, farmer, interested in animals and Indian lore" (DB, 6). If the protagonist of On the Road, Dean Moriarty, was "the perfect guy for the road, for he was born on the road" (Kerouac, 1957, 7), Japhy Ryder is the perfect man for the wild, "a tough little adventurer of trails and mountains" (DB, 53). He grew up among animals in the wild forests of the Northwest, is well versed in ornithology and knows many first-hand stories about animal encounters by real outdoorsmen. Everything in him evokes animality: his goatee, his slanted green eyes, his natural instincts in the wild, "the vigorous long steps he takes" (40), the way he takes off his clothes to walk naked as a jaybird or jumps from rock to rock like a mountain goat.

After eating "a man's breakfast," Ray, Japhy and their friend Morley set out for the wild mountains of the Sierra Nevada, tramping on trails and drinking from water places used by wild animals, Indians and trappers before them. The more they walk, the less they talk, as if words had become an unnecessary (cultural) supplement to animal (natural) instincts, to the point that "there's just no need to talk, as if we were animals and just communicated by silent telepathy" (46). After walking through "a little glen of the Forest of Arden" (49), Shakespeare's primitive forest in As You Like It, they eventually reach a plateau where they camp under the starry night. The following day, Japhy takes Ray for a climb up Matterhorn Peak, a long, tough hike which brings him close to total exhaustion, his efforts eventually earning him "the title of Tiger," as if he had been transformed into the "proud animal" of primitive times in the process: "I really felt proud. I was a Tiger," Ray remarks, adding that he "will be a lion next time we get up here" (65). On top of Matterhorn, Japhy lets out a "triumphant mountainconquering Buddha Mountain Smashing song of joy," a call of the wild of sorts which forces his admiration in masculine terms: "I had to hand it to him, the guts, the endurance, the sweat" (63). On his way down, Ray then follows traces of a deer trail, alone in the woods looking for tracks and excrement, as if his animal instincts and primitive senses had been aroused by his coming into contact with the wildlife around him:

I was a hundred yards from the other boys and walking alone, [...] along the little black cruds of a deer trail through the rock, no call to think or look ahead or worry, just follow the little balls of deer crud with your eyes cast down and enjoy life. I followed my deer trail so assiduously I was by myself going along ridges and down across creek bottoms completely out of sight [...] but I trusted the instinct of my sweet little millennial deer and true enough, just as it was getting dark their ancient trail took me right to the edges of the familiar shallow creek (where they stopped to drink for the last five thousand years). (65-66)

13 The flight into the wild enables Kerouac's narrator to deterritorialize the prevailing model of masculinity-that of the domesticated white-collar worker, merging as he does with the wildlife that surrounds him as he slowly progresses into the animal realm. Simultaneously, he reterritorializes a heroic masculine identity, that of the adventurous frontiersmen, sometimes suggesting a regression into animality and the conquest of a virgin land. ${ }^{12}$ In this respect, Kerouac's outdoors stories are not unlike 
those found in men's adventure magazines and their quest for real masculinity in the most remote, wild and uninhabited areas in the world.

Yet, large wild animals remain mostly invisible, simply providing the protagonists with tracks and other signs of life which are left for the poet to decipher. What Kerouac's protagonist and readers are left with are traces of animal life, signs of passage, of their fleeting presence and overwhelming absence. The very title of Kerouac's two-month retreat in the Cascade Mountains the following year, Desolation Angels, explicitly expresses the sense of solitude and stillness that he experienced in the American wilderness. Kerouac's narrator and alter ego, Jack Duluoz, describes his environment as made up of rocks and trees upon which the wind blows, which leads him to reconsider his approach to the animal realm.

\section{Masculinity in the Garden of Eden: A Caterpillar, Two Mosquitoes and a Baby Chipmunk}

On a small hike not far from the shack where he sleeps and looks out for signs of animal life, Jack Duluoz realizes with horror and dismay the absence of living creatures and the silence that accompanies it, as if the entire world had abandoned him. He decides for fun to push a boulder off a 500 meter cliff as if to hold himself company, but the harsh sound of the rock splitting in two reinforces his sense of solitude: "Silence, the beautiful gorge shows no sign of animal life, just firs and alpine heather and rock, the snow beside me blinds whitely in the sun, I loose down at the cerulean neutral lake a look of woe, little pink or almost brown clouds hover in its mirror" (DA, 51). Faced only with an uncanny mineral world of rock, water, clouds and snow that offers neither challenge nor company, the protagonist is left looking sadly at his own reflection.

This poetics of absence transforms the representation of masculinity traditionally found in adventure stories. American wildlife is not considered as a hostile environment offering a series of challenges in which men can assert their masculinity, but as an eternal Garden of Eden, a homosocial world in which Eve has not yet set foot. Kerouac's narrator refers to "the Emily Dickinson afternoon of peace and ah butterflies" (109), thus rooting his representation of the wilderness in bucolic romanticism. In a revival of the mid- $19^{\text {th }}$ century romantic imagination of Transcendentalist writers like Ralph Waldo Emerson and Henry David Thoreau, the protagonists are shown as men of feelings. Smaller, less dangerous and less considered animals come to the forefront in a bestiary that is essentially composed of bugs, insects, gnats, mice, rats and other rodents that either sting him or eat his food, without any resentment on his part. He goes as far as to feed an old bottle of maple syrup to a colony of ants and to admire the work of the woodworm that eats out his table-"in, up, twirl, green worm leaves wrung out of toil" (78). Duluoz develops a strong connection with those few animals that offer him company in this solitary life, peppering his narrative with vignettes of those neighbors of his. He enjoys recording the transient, fragile life that people his solitude, using pastoral conventions of eternity and harmony: "Flights of gray birds come merrying to the rocks of the yard, look around awhile, then start pecking at little things-the baby chipmunk runs among them unconcerned-The birds look up quickly at a fluttering yellow butterfly" (90). He desires to partake in this pastoral scene of innocence, but realizing that it would 
constitute "a frightful imposition on their little beating hearts" (ibid.), he eventually refrains from it and remains at a distance.

The poet-narrator himself becomes an animal among others, another companion species from this heavenly wilderness, presenting those significant others as instinctual kin ${ }^{13}$ : "after all that winter in the woods of night I had to hear the little sounds of animals and birds and feel the cold sighing earth under me before I could rightly get to feel a kinship with all living things" (DB, 129). Jack goes on to transcribe the sounds of those various tiny animals, animalizing writing to a considerable extent, from "the wick wicky wick of a bird" or "the bizong bizong of morning flies" to "the big mosquitoes of straw that smile on the moon [...] going bzzz," the "eeeing little bug [which] dingly lingers whingeing sings morning void devoid of loi" (DA, 78), or the "'drit drit drit' of a flock of birds and the 'hark-hark-hark' of the hawks" (DB, 106). Animal sounds become signs that are transcribed and interpreted by the poet-narrator, whose skills in animal language demonstrate how familiar he has become with the wild. Animal sounds become poetic ciphers, and the simple croaks of a frog seem to convey a mystical meaning which he unfolds for his reader: "once at high noon a frog croaked three times and was silent the rest of the day, as though expounding me the Triple Vehicle. Now my frog croaked once. I felt it was a signal meaning the One Vehicle of Compassion" (108) which in his mind confirms his "kindness to animals" (109). In this idealized representation of man / animal relationship, Kerouac seems to rewrite the theme of the new Adam returning to Eden and to trade his earlier perception of men as proud animals for a more comprehensive understanding of the wild as a sacred ecosystem in which interspecies conversation is possible.

In this perspective, all wildlife seems animated by a holy spirit, resulting in a holistic vision of animality. Animals and men are tied in harmony, instead of being opposed as antagonists. The rat, commonly despised for its association with the plague, is here described as a theriomorphic manifestation of the divine, "the millennial ratTheriomorphous, highest perfect Rat" (DA, 79). Even pests are shown as part of a holistic natural world in which men and animals merge together, as the narrator suggests in his hospitality to mosquitoes: "One night I was meditating in such perfect stillness that two mosquitoes came and sat on each of my cheekbones and stayed there a long time without biting and then went away without biting" (DB, 143). In Kerouac's romantic wilderness, wild animals are not antagonists, but are tied instead by a reciprocal kindness tinged with childlike naiveté. Everything happens as if animals could sense the poet's overflowing peacefulness and enlightenment, echoed and celebrated by ethereal "aviaries of magic transcendent birds recognizing my awakening mind with sweet weird cries (the pathless lark)" (112). All signs of cruelty, even between animals, are evacuated, in a most candid, yet humorous representation of the wild, like those birds "drooping little fresh turds surprising cats who wanted to eat them a moment ago" (155). In this series of religious vignettes narrating experiences of romantic epiphany, animals are transcended into disembodied ideals of sublime harmony without entirely losing their earthly, base materiality.

A sense of neighborliness pervades Kerouac's descriptions of the wild, which are thereby reminiscent of Thoreau's relationship to those "brute neighbors" and "winged friends" of his at Walden Pond. For both authors, the animals which people their lonesome retreat become "beasts of burden, in a sense, made to carry some portion of our thoughts" (Thoreau, 216). In those blissful scenes sketched on the spot in the 
instantaneous present, animals are shown as good and benevolent, so that they come to differ markedly from the radical otherness and the evil nature of the wild beasts that made up the masculine imagination in men's adventure stories. The wilderness here is not a battlefield where men and ruthless animals are set in opposition, nor a hostile land of savagery, but a restful Garden of Eden. They do not recount the great deeds of heroic men in challenges in which they could test their manhood, but represent the possibility of harmonious unity and peaceful innocence prior to the fall into civilization. In this Edenic vision, wild animals become strangely familiar, almost merging into "individuated animals, family [familiers familiaux] pets, sentimental, Oedipal animals" which Deleuze and Guattari despise (Deleuze et Guattari, 2004b, 265). The domestic / wild dichotomy is blurred in Kerouac's Garden of Eden, and the poetnarrator reconstructs an oikos (literally 'house' in Ancient Greek) in the company of wild animals. ${ }^{14}$

Indeed, instead of being confronted with roaring bears, gnarling wolves, or venomous snakes, Duluoz only comes into contact with small, inoffensive animals that he reimagines in a collage of various species. In his bestiary of seemingly insignificant animals, Kerouac's narrator provides for instance an insight into the daily life of a green alpine caterpillar to which he devotes a whole chapter in Desolation Angels. He patiently describes its slow move along a branch, its eating heather with "a head like a pale dewdrop" and its "fat body reaching up straight to climb" (DA, 58). But as if to render this portrait more vivid and more captivating for the reader, Duluoz compares the tiny insect to bigger, more exotic animals: it moves and hangs upside down "like a South American ant eater," it sometimes stops "motionless like the picture of a boa constrictor," "sleeps snakeheaded" and is also at times "playing possum as he twists" (58). This multiplicity of comparisons blurs the distinction between different species, putting in perspective similarities rather than pointing out differences, to the point that the caterpillar is described as "cromming up like a boy making a limb" (58). So much so that the caterpillar ends up resembling a strange mythological, composite animal of his own making. Likewise, when he spots several fawns eating a plate of cold boiled potatoes he has laid out for them, he describes them as "unreal, too skinny, too strange to be deer, but new kinds of mystery mountain mammals" (42). In spite of his intimacy with wild animals, the latter remain strange mysterious beings that resist classification and identification and that cause a feeling of frightening unfamiliarity, Unheimlich-literally "unhomely," undomesticated. As such, Kerouac's bestiary is closer to Jose Luis Borges' Book of Imaginary Beings than to a zoologist account on animal life, and just as fanciful as medieval bestiaries.

\section{Of Bugs, Mice and Men: Death, Compassion and Hospitality}

21 This excessive identification with small animals during his solitary stay on Desolation Peak leads Kerouac's narrator to observe animal suffering from closer. Yet, the reader does not witness the spectacular, violent death by guns, but the slow agony of those insignificant animals. He thus projects on these animals an interiority that blurs the distinction between human and non-human; simultaneously, the consciousness of a shared destiny towards death opens up a space for communication and compassion that challenges traditional male encounters with wild animals. In Desolation Angels for 
instance, the narrator, Jack, witnesses the pathetic struggle of dying bugs in his cabin, as if the few living beings he actually came in contact with offered him evidence of the evanescence and futility of existence:

bugs thrash in mortal agony even on the table as you'd think, deathless fools that get up and walk off [...], like us, 'hooman beens'-like winged ants, the males, who are cast off by the females and go die, how utterly futile they are the way they climb windowpanes and just fall off when get to the top, and do it again, till they exhausted die-And the one I saw one afternoon on my shack floor just thrashing and thrashing in the filthy dust from some kind of fatal hopeless seizure-oh, the way we do, whether we can see it now or not. (63)

Animals simply are smaller beings for Jack, they do not belong to a different order: they are like a precipitate of human life, a microcosm that condenses and mirrors his own life and death. The bug's desperate escape and struggle for life seems to parallel his equally desperate attempt to flee from domesticity. The scene repeats itself at the very end of the narrative, leaving little room for anything but dark pessimism, especially since this time he is responsible for the bug's death, the latter getting caught in the drying paint of one of his artworks (as it would on vulgar flypaper) in a (de)sublimation of the creative act:

I spend the last thirty minutes of twilight trying to extricate the little bug from my sticky masterpiece without hurting it or pulling off a leg, but no go-So I lie there looking at the struggling little bug in the paint and realize I should never have painted at all for the sake of that little bug's life, whatever it is, or will be-And such a strange dragon-like bug with noble forehead and features-I almost cry-The next day the painting is dry and the little bug is there, dead-In a few months, his dust just vanishes away from the painting altogether. (389)

In the way this passage underlines the insignificance of life through the death of an insignificant animal, it echoes Virginia Woolf's and Annie Dillard's "Death of a Moth," yet it neither displays the emotional restraint of the former, nor the unsentimental details of the latter. Contrary to men's adventure stories in which the characters would never let the slightest emotion surface when taking the life of an animal, Jack sheds tears on his companions' agony, a sign of effeminate squeamishness according to the dominant standards of masculinity of the times. "Boys don't cry" as the saying goes; yet, in Kerouac's Legend, mature men do at the sight of a dying bug.

Beyond the existential lyricism of such passages that sometimes verge on downright pathos, the narrator strongly rearticulates the original domestic/wild binary opposition of The Dharma Bums-dog/wolf, cat/lion, civilized animal/proud animal. In this liminal space between civilization and savagery, species meet in their shared experience of suffering and death. While the prime masculine virtue in the wild is traditionally that of courage, especially in hunting narratives in which virile men confront themselves to deadly animals, Kerouac makes compassion (the feminine counterpart to masculine bravery in popular culture) his main goal in the narrative and the main teaching he receives in this animal world, in a striking re-articulation of gender stereotypes. ${ }^{15}$ Simultaneously, the animal / human frontier becomes indistinct. In his eyes, there is no greater violence that in denying animals the possibility of their own death by refusing to grant them any consciousness of it; as such, Jack's elegiac description (and mourning) of the dying bug is a "gift of death" that compensates for his taking its life. ${ }^{16}$

Shortly before he leaves Desolation Peak, Jack engages in the only hunting scene of the novel, not the heroic big-game chase of traditional hunting narratives, but a small-scale mouse hunt that brings him to the verge of tears once again. In this anticlimactic 
confrontation between man and animal, the narrator underlines the humanity of the mouse's frightened gaze: "I murdered a mouse which was-agh-it had little eyes looking at me pleadfully, [...] it looked at me with 'human' fearful eyes [...], little angel wings and all I just let her have it, right on the head, a sharp crack, that killed it, eyes popped out covered with green pea dust" (94). The exchange of looks between man and animal opens up a space for compassion, as if the eyes were a site where the human / animal binary eroded. Though the mouse's bulging eyeballs provide evidence of human cruelty, the narrator's second encounter with a mouse's gaze leaves him as defenseless as the mouse he is chasing, especially after he has found "a drowned mouse elongated like a ghost" in a water trap that had been set by the previous occupant of the cabin: "Ah murdered 2 mouses, and attempted murder on a third, which, when finally I caught it standing on little hind legs behind the cupboard with a fearful upward look and its little white neck I said "Enough,"' (95). The animal gaze seems to shatter his sense of self, as if the humanization of the mouse had made him realize his own bestiality, which leads him to portray himself as "an angel with wings dripping with blood of my victims" (96): "Don't laugh-a mouse has a little beating heart, that little mouse I let live behind the cupboard was really 'humanly' scared, it was being stalked by a big beast with a stick and it didn't know why it was chosen to die-it looked up, around, both ways, little paws up, on hind legs, breathing heavily-hunted" (ibid.). The various encounters with mice create a fluidity of identities that blurs the human/ animal dichotomy, as if the exchange of gazes had prompted an exchange of selves between the "humanly scared" mouse and the "big beast" that he has become. ${ }^{17}$ Kerouac's narrator seems to be exposed by the mouse's helpless gaze. Beyond language or reason, it is their common experience of suffering that ties them together, the passage providing a positive answer to Jeremy Bentham's crucial question: "can they suffer?"18 Besides, Jack comes to question one of the traditional incentives for manly behavior: "Expressions like 'Are you a man or a mouse?' began to hurt me" (95) he reflects. ${ }^{19}$ Clearly, his compassion for the dead mouse-literally his suffering with the mouse, his sharing its pain-leads him to question such binary alternatives, as if he had sided with the mice against men's (and his own) cruelty towards animal life. His flight into the wild in search for an undomesticated form of masculinity thus eventually ends in a failure to achieve the expected outcome, revealing instead the gendered bias that underpinned such an ambivalent move towards animality. Closer to the mouse (which he decides to bury in a domestication of death in the wild) than to the lion he was hoping to become, Kerouac's narrator exits the wilderness with a keen sense of the inadequacy of such metaphors and a troubled notion of who he is: "as I [...] come down the mountain I can't for the life of me be anything but enraged, lost, partial, critical, mixed-up, scared, foolish, proud, sneering, shit shit shit" (97).

To understand such an outcome, we should probably stop following Kerouac's narrator's escapist fantasy about deer trails and follow instead the traces of mice in his Legend, traces which take us back to his childhood home in Lowell, Massachusetts. His compassionate empathy towards animals comes, he writes in "The Origins of the Beat Generation," from a teaching "delivered to [him] by the men in [his] house" that takes the form of a commandment against speciesism ${ }^{20}$ : "never hurt any living being, all living beings whether it's just a little cat or squirrel or whatever, all, are going to heaven straight into God's snowy arms so never hurt anything and if you see anybody hurt anything stop them as best as you can" (Kerouac, 1993a, 64). As a kid, Kerouac remembers being marginalized "for stopping the younger kids from throwing rocks at 
the squirrels, for stopping them from frying snakes in cans or trying to blow up frogs with straws" (ibid.). In Visions of Gerard, Kerouac pictures his father as a saintly man who "never lifted a hand to punish me, or to punish the little pets in our house" while he praises his brother as a little angel who gave hospitality to a mouse caught in a trap:

The little mouse, thrashing in the concrete, was released by Gerard-It went wobbling to the gutter with the fish-juice and spit, to die-He picked it tenderly and in his pocket sowed the goodness-Took it home and nursed it, actually bandaged it, held it, stroked it, prepared a little basket for it [...]-I don't remember rationally but in my soul and mind Yes there's a mouse, peeping, and Gerard, and the basket, and the kitchen, the scene of this heart-tender little hospital-'That big thing hurt you when it fell on your little leg' (because Gerard could really feel empathetically the pain, pain he'd had enough to not be apprentice at the trade and pang)- $\mathrm{He}$ could feel the iron snap grinding his little imagined birdy bones and squeezing and cracking and pressing harder unto worse-than-death the bleak-in-life. (Kerouac, 1991, 8-9)

Contrary to the false hospitality of the mouse trap, by which mice mistake a deadly stratagem for a generous offer of a piece of cheese, Gerard is described, in a crossgender performance, as a nurse offering maternal care, their home transformed into an animal clinic of sorts ${ }^{21}$. This hospitality helps us understand Kerouac's narrator's attitude towards small animals in the wild. Though he first represents wilderness as a refuge from domesticity, he ends up domesticating the wild in offering hospitality to small animals. We touch here the heart of Kerouac's ecopoetics, which as Jonathan Skinner reminds us, is more than just poetry about nature and animals: 'Eco' here signals-no more, no less-the house we share with several million other species, our planet Earth. 'Poetics' is used as poesis or making, not necessarily to emphasize the critical over the creative act (nor vice versa). Thus: ecopoetics, a house making" (Skinner, 5). Paradoxically, while Kerouac tried to escape oikos-the feminine space of home as well as the economic responsibilities linked to the household and the family, his representation of the wild is eventually founded on a poetics that follows the very logics of oikos, an ecology of sorts that hosts together bugs, mice and men, but from which women (and huntsmen) are left out. In the end, for Kerouac as for John Muir, "[g]oing to the woods is going home" (Muir, 98), but a home without women.

\section{Avalokitesvara the Bear, Hunting as Murder and the Erotics of Male Predation}

After this experience of compassion and hospitality in the company of bugs and mice, Kerouac's narrator comes to realize how hostility towards animals is ingrained in men's vision: "When big cow-y deer grazed in my moonlight yard still I stared at their flanks as with a rifle sight-tho I would never kill a deer, which dies a big death-nevertheless the flank meant bullet, the flank meant arrow-penetrating, there is nothing but murder in the hearts of men" (DA, 96). The male gaze of the narrator is here consciously defined both through the sexual metaphor of penetration and through its inherent violence suggested by terms like "kill," "rifle," "bullet," or "arrow." Interestingly enough, this visual pleasure of male predation is precisely the organizing principle of the many hunting stories that filled the pages of men's adventure magazines at the time, along with erotic pictures of lightly dressed pin-ups. Not only did those magazines glorify narratives of male predation, most notably through bear hunting 
fantasies, but their (mostly male) readers were invited to identify with the irresistible excitement of the "rifle sight." However, at a time when many American men "were suffering from an outmoded masculine mystique that made them fell unnecessarily inadequate when there were no bears to kill" in Betty Friedan's own words (Friedan, 386), Kerouac's depictions of bear encounters diverged strongly from the erotics of male predation to be found in bear hunting stories that were so popular among male readers at the time. ${ }^{22}$

Indeed, bears hunting stories were a regular fixture in fiction for men from the 1950s. In the February 1950 issue of True-subtitled "The Largest Selling Man's Magazine," a grizzly bear is shown running toward the reader through the sight of a rifle that frames the magazine cover, hereby introducing a short story about the hunting feats of a runaway struggling for his life in the wild mountains of Wyoming. The strong and physical protagonist, Earl Durand, is constructed as a hard, strong man, described as "animal-like," eating animal flesh for his sustenance, "and it made little difference to him whether he ate this meat raw or cooked." Hunting for Durand is presented as a matter of survival, a necessity that disregarded game laws and hunting seasons, which "were intended for men to whom shooting is a pastime" (Haugh, 86). In the same vein, the April 1958 issue of Outdoor Adventures-which claimed to feature "Hard-hitting Action for Rugged Men"-offered its reader an exciting account entitled "I was Loaded for Bear" in which an old German hunter tells the story of his search, encounter and struggle with a grizzly bear in Alaska. After spotting normal size bears, the narrator comes face-to-face with "the big one," which "weighed more than two thousand pounds and [...] was over ten feet," so that it will take two bullets in the chest, one in the shoulder and a final shot in the head to bring him down for good, and that "four men couldn't turn him over on his back for skinning" (Melchior, 75). In these accounts, the male hero is systematically constructed as the embodiment of the male warrior, as primitive, dangerous and brave as the "monsters" he fights against. The narrator's gaze, like Kerouac's "rifle sight," is structured around a visual economy of erotic violence in which the reader actively participates. Hunting here enables to stave off the feminizing and emasculating effects of modern civilization and functions as a test of manhood that allows the hunter (and the reader) to re-assert his masculine identity through violence and death, in a fantasy of wilderness constructed as the antithesis of the domestic, feminine space of home. ${ }^{23}$

In Kerouac's The Dharma Bums, the three male characters meet a group of hunters who seem to come precisely out of one of those hunting stories featured in men's adventure magazines. On the road to the hike's starting point, at the northern boundary of the Yosemite National Park (which the narrator dubs the "whisky country of hunters"), they stop at a "roadhouse all done up in the upcountry mountainstyle, like a Swiss chalet, with moose heads and designs of deer on the booths and the people in the bar itself an advertisement for the hunting season" (DB, 33). On the eve of the opening of the hunting season, the arrival of this strange group of bohemian-looking hikers from the city raises the suspicion of those "many hunters in red caps and wool shirts looking silly getting loaded, with all their guns and shells in their cars and eagerly asking us if we'd seen any deer or not" (32), so that "when they heard we were out in this country not to kill animals but just to climb mountains they took us to be hopeless eccentrics" (34). Set in sharp opposition-us/them, climbing/hunting, young city intellectuals/old country bumpkins, the two groups are set as two diverging brands of masculine 
identity. After ordering glasses of port wine (and not whisky like those real huntsmen), Japhy, the narrator's mentor goes on to formulate a religion-based criticism of hunting that presents it as straight and simple murder: "I hate these damn hunters," he says, "all they want to do is level a gun at a helpless sentient being and murder it, for every sentient being or living creature these actual pricks kill they will be reborn a thousand times to suffer the horrors of samsara" (33). ${ }^{24}$ Contrary to the hunter, who is defined through his antagonism to animals, the poet posits a responsibility towards the animal, confirming Deleuze's suggestion that "writers [...] experience the animal as the only population before which they are responsible in principle [de droit]" (Deleuze and Guattari, 2004b, 265). When he spots a deer "leaping in the shrubbery by the side of the road and disappearing into the sudden vast diamond silence of the forest [...] running off to the haven of the raw fish Indian up there in the mists," the narrator addresses the deer instead of shooting him, assuring the animal of their peaceful intentions: “'Hey little deer,' I'd yelled to the animal, 'don't worry, we won't shoot you'" (32-33). The violent confrontation with wild animals to be found in men's adventure magazines is here replaced by peaceful communication; yet, the animal does not respond. ${ }^{25}$ Samsara (often translated by wheel of suffering), the Sanskrit term that refers to the feminine cycle of birth and death in Buddhism (and the antithesis of Nirvana), is essential to understanding Kerouac's gendered representation of the wild and accounts for his subsequent feminization of hunting. In Kerouac's Christian-Buddhist perspective, animals are both God's creations and reincarnations of the Buddha. In his eyes, killing animals can only amount to a sin or to samsara, both defined in terms of femininity. Kerouac's criticism of hunting thus represents an important twist on the masculine mystique of the times, on the social function of hunting as a ritual of manhood and on the masculine fantasies of animality to be found in men's adventure magazines. The rifle as phallic symbol is deflated along with the erotics of male predation inherent in hunting. Yet at the same time, his poetics is structured on a gendered worldview that reproduces an image of women as life threatening, Jack the narrator and Jack Kerouac the author having both taken a vow of chastity: "I'd also gone through an entire year of celibacy based on my feelings that lust was the direct cause of birth which was the direct cause of suffering and death and I had really no lie come to a point where I regarded lust as offensive and even cruel" (21). Sexual desire, like hunting, is dismissed as a threat to natural harmony and as downright bestiality, in keeping with the pastoral tradition of the male hero as an archetype of presexual innocence. ${ }^{26}$

31 Kerouac actually deconstructs the inherent violence of bear hunting narratives through the figure of "Avalokitesvara the Bear," first mentioned at the closing of The Dharma Bums and further described in Desolation Angels. Kerouac's depiction of the bear self-consciously rewrites the topoi of bear hunting stories and eludes the traditional representation of animality to be found in male adventure magazines. One morning, Jack Duluoz wakes up and finds "bear stool and signs of where the unseen monster has taken cans of frozen hardened can-milk and squeezed it in his apocalyptical paws and bit with one insane sharp tooth, trying to suck out the sour paste" (DA, 83). Though feces are traditional signs used by hunters to date an animal's passage, and though the cans torn to pieces provide signs of the bear's savagery, Duluoz neither tries to hunt it, nor will he even catch sight of it. Instead, he is left to reconstitute the imaginary wanderings of the deadly animal: "He will not show himself in the mystery of those silent foggy shapes, thou I look all day, as thou he were the inscrutable Bear that can't 
be looked into" (ibid.). Though Kerouac's narrator describes the bear as a ferocious animal at first-"King Bear who could crush my head in his paws and crack my spine like a stick" (ibid.), he quickly transforms into an invisible deity whom he crowns King of American wildlife, a supernatural deity who "owns all the Northwest and all the Snow and commands all mountains" (ibid.). Instead of acting as a foil to the narrator's virile manliness, the bear embodies the eternal, infinite nature of life on earth, in keeping with his Buddhist belief in reincarnation: "He has millenniums of thusprowling here behind him-He has seen Indians and Redcoats come and go, and will see it again" (ibid.). Nature is not a battleground in which the bear is set as radical other, but an original, still pacific state of nature in which he is a fellow congener.

The bloodthirsty bear of hunting stories becomes in his mind a caring, benevolent, and nurturing figure: "He is a tender silent thing crawling towards me with interested eyes [...]. The Bear will carry me to my cradle-He wears on his might the seal of blood and reawakening" (ibid.). The narrator deconstructs the traditional scenario of the hunting story, replacing the erotics of male predation by a fantasy of maternal care. ${ }^{27}$ Outside the cycle of birth and death, Kerouac's bear is a life-giving principle, an affectionate maternal figure devoid of aggressiveness. In this passage, the blood as a mark of the violent history of the conquest of the Wild West is transmuted into the Christian symbol of resurrection, while the cradle to which the narrator is carried announces a rebirth. The narrator's manliness is not regenerated by violence but by umbilical connection. Instead of a manly confrontation or of a ritual of passage to manhood as one would expect from such a narrative of flight into the wild, the most dangerous of wild animals on the American continent turns out to be the vehicle of peaceful communion and mutual benevolence. While men's adventure magazine essentially staged male grizzlies for they were bigger game than females, the narrator feminizes the animal and stages himself as an infant child, not as a "real man." As an animal manifestation of Avalokitesvara, the androgynous deity of compassion in Buddhism, Kerouac's bear represents a twist on the image of the bear as a pitiless predator. ${ }^{28}$ Yet, Jack's fantasy of animal communion empower women only marginally in the role of the Good Mother, paradoxically resorting to the embodiment of domestication that he fled from in the first place to revitalize his sense of manliness.

\section{Conclusion}

Against conventional images of Kerouac as a popular icon of youth rebellion, as a "wild man" whose "liberation of the senses and of instinctual drives evoked images of a wild beast about to set upon society at large" (Bacciocco, 13), I tried to show how Kerouac's poetics revolved instead around romantic notions of compassion and sentimentality, transforming the inhospitable wilderness of men's adventure magazine into a world of reciprocal harmony, hospitality and kinship. ${ }^{29}$ In an essay published in February 1958 entitled "Lamb, No Lion," Kerouac reacted to such misrepresentations of his novels, drawing up an animal fable to express "the dream of the Beat Generation," a dream actually not unlike the 1950s American dream of domestic bliss and family life: "I had a dream that I didn't want the lion to eat the lamb and the lion came up and lapped my face like a big puppy dog and then I picked up the lamb and it kissed me" (Kerouac, 1993, 54). A domestic writer rather than a bold adventurer, Kerouac did not write The Dharma Bums surrounded by wild animals in the great outdoors, but laterat his mother's 
home in Florida in the company of his cat. ${ }^{30}$ At the end of Desolation Angels, he sadly reflects about the domestic life he has finally come to adopt: "I'm so sunk now, so unexcited, [...] tho at least, since I live with Memere in a house of her own miles from the city, it's a peaceful sorrow. A peaceful sorrow at home is the best I'll be ever be able to offer the world" (397). His poetics feeds on domestic images that are resolutely at odds with his popular and critical perception as a wild and rebellious writer.

Though Kerouac's often misogynist ethos-his fear of women's growing power and of men's resulting emasculation, as well as his desire to masculinize American cultural expressions through his narratives of flight from domestication-should not be downplayed, his poetics represents a twist on gender norms and evades simple categorization. As feminist critic and Beat scholar Ann Douglas remarked, the fact that "the Beats dismantled conventional ideas of masculinity, disavowing the roles of breadwinner, husband, and father and incorporating homosexual, even 'feminine' traits into the masculine ideal, has seemed to many feminist critics less important than their sometimes openly misogynist ethos" (Douglas, xiv). Indeed, Kerouac achieves a profound re-articulation of gender stereotypes through animality, based as it is on notions of care, nurture and companionship, without fully incorporating wildlife through conquest or domestication. While Kerouac may seem at odds with Gary Snyder's deep ecological awareness (just as Ray is at odds with Japhy's wide erudition in the ways of Buddhism and wildlife in The Dharma Bums), his fiction nonetheless bears witness to his compassionate understanding of animal life; as such, it announces and exemplifies what Snyder calls "the practice of the wild" in his book of the same name, an experiencing of the common grounds that we share with animals beyond the dichotomy between the civilized and the wild. The Beats, and Kerouac in particular, paved the way for a greater concern about environmental matters and for a critical reassessment of men's attitude towards animals and of men's perception of themselves as men.

\section{BIBLIOGRAPHY}

ADAMS, Carol J. and DONOVAN, Josephine, Animals and Women: Feminist Theoretical Explorations, Durham, Duke University Press, 1999.

ALLISTER, Mark Christopher, Eco-man: New Perspectives on Masculinity and Nature, Charlottesville, University of Virginia Press, 2004.

BACCIOCCO, Edward J., The New Left in America: Reform to Revolution, 1956 to 1970 Stanford, Hoover Institution Press, 1974.

BHABHA, Homi, “Are You a Man or a Mouse?" in BERGER, Maurice, Constructing Masculinity, New York, Routledge, 1995.

BURROUGHS, Edgar Rice, Tarzan of the Apes [1914], New York, Signet Classics, 1990.

CABEZON, José Ignacio, Buddhism, Sexuality, Gender, Albany, State University of New York Press, 1992. 
CARROLL, Bret E., American Masculinities: A Historical Encyclopedia, New York, Sage, 2003.

COLERIDGE, Samuel, Collected Letters of Samuel Taylor Coleridge, London, Oxford University Press, 1969.

DELEUZE, Gilles, Difference and Repetition, London, Continuum, 1994, originally published as Différence et répétition [1968], Paris, PUF, 1985.

DELEUZE, Gilles, and Guattari, Felix, Anti-Oedipus [1977], London, Continuum, 2004a, originally published as L'Anti-@edipe, Paris, Minuit, 1972.

---, A Thousand Plateaus [1987], London, Continuum, 2004b, originally published as Mille Plateaux, Paris, Minuit, 1980.

DERRIDA, Jacques, Aporias, Stanford, Stanford University Press, 1993, originally published as “Apories. Mourir-s'attendre aux limites de la vérité" in Le Passage des frontières, Paris, Galillée, 1993.

---, The Beast and the Sovereign: Volume 1, Chicago, The University of Chicago Press, 2009, originally published as Séminaire La Bête et le Souverain: Volume 1, 2001-2002, Paris, Galillée, 2002a.

---, “The Question of 'the Animal”' in Derrida, dir. by Kirby Dick and Amy Ziering Kofman, Jane Doe films, 2002b.

---, "The Animal that Therefore I Am (More to Follow)" in Critical Inquiry, vol. 28, No. 2, (Winter, 2002a), originally published as "L'Animal que donc je suis (à suivre)" in L'Animal autobiographique, Paris, Galillée, 1999.

DOUGLAS, Ann, “Preface”to Johnson, Joyce, Minor Characters [1983], New York, Penguin, 1997.

FIEDLER, Leslie A., Love and Death in the American Novel [1960], London, Paladin, 1970.

FRIEDAN, Betty, “Epilogue” to the Feminine Mystique [1963], New York, Dell, 1983.

HARAWAY, Donna, The Companion Species Manifesto: Dogs, People and Significant Otherness, Chicago, Prickly Paradigm Press, 2003.

---, When Species Meet, Minneapolis, University of Minnesota Press, 2008.

HAUGH, Donald, “The Eleven Days of Earl Durand” in True: The Man's Magazine, February 1950, 26 and 86-90.

HINMAN, Lawrence M., Ethics: A Pluralistic Approach to Moral Theory, Belmont, CA, Wadsworth, 2008, 4th edition.

KEROUAC, Jack, “'A Noble Experiment,' Subject: What will my books be about this summer?”, unpublished, New York Public Library Archive, Berg Collection, 6.13, 1941.

---, On the Road [1957], New York, Essential Penguin, 1998.

---, The Dharma Bums [1958], New York, Penguin Classics Deluxe Edition, 2006.

---, Lonesome Traveler [1960], New York, Penguin Modern Classics, 2000a.

---, Visions of Gerard [1963], New York, Penguin, 1991.

---, Desolation Angels [1965], London, Flamingo, 1996.

---, Visions of Cody [1960 et 1972], Penguin, New York, 1993a.

---, "The Origins of the Beat Generation" [1959], Good Blonde and Others, San Francisco, City Lights, 1993b. 
---, Selected Letters II, New York, Penguin, 2000b.

KIMMEL, Michael, Manhood in America, New York, Oxford University Press, 2006.

KOLODNY, Annette, The Lay of the Land: Metaphor as Experience and History in American Life and Letters, Chapel Hill, University of North Carolina, 1975.

KRAKAUER, Jon, Into the Wild, New York, Villard, 1996.

LEE, Raymond L. M. and ACKERMAN, Susan Ellen, Sacred Tensions: Modernity and Religious Transformation in Malaysia, Columbia, University of South Carolina Press, 1997.

LEWIS, Richard W. B., The American Adam, University of Chicago Press, 1959.

LUKE, Brian, Brutal: Manhood and the Exploitation of Animals, Chicago, University of Illinois Press, 2007.

LEVERENZ, David, "The Last Real Man in America" inMURPHY, Peter F., Fictions of Masculinity: Crossing Cultures, Crossing Sexualities, New York, NYU Press, 1994, 21-53.

MELCHIOR, Lauritz, “I was Loaded for Bear” in Outdoor Adventures, April 1958, 38-43 and 75-76.

MELVILLE, Peter, Romantic Hospitality and the Resistance to Accommodation, Waterloo, Wilfrid Laurier University Press, 2007.

MONAGHAN, Patricia, Goddesses in World Culture, Santa Barbara , Greenwood, 2010.

MUIR, John, Our National Parks [1901], New York, Cosimo, 2006.

NASH, Roderick, Wilderness and the American Mind, New Haven, Yale University Press, 1967.

NELSON, Barney, The Wild and the Domestic: Animal Representation, Ecocriticism, and Western American Literature, Reno, University of Nevada Press, 2000.

PARFRAY, Adam, It's a Man's World: Men's Adventure Magazines, the Postwar Pulps Los Angeles, Feral House, 2003.

PHILLIPS, Rod, "Forest Beatniks" and "Urban Thoreaus": Gary Snyder, Jack Kerouac, Lew Welch and Michael McLure, New York, Peter Lang, 2000.

PODHORETZ, Norman, "The Know-Nothing Bohemians" in Doings and Undoings: The Fifties and After in American Writing, New York , Farrar, Strauss, 1964.

SCHLESINGER, Arthur M., "The Crisis of American Masculinity" [1958], reprinted in The Politics of Hope [1963], Princeton, Princeton University Press, 2008, 292-303.

SKINNER, Jonathan, “Editor's Statement” in ecopoetics, n. 1, 2001, 5-8.

SNYDER, Gary, The Practice of the Wild [1990], Berkeley, Counterpoint, 2010.

SPENGLER, Oswald, The Decline of the West II, New York, Knopf, 1928.

SUBERCHICOT, Alain, Littérature américaine et écologie, Paris, L'Harmattan, 2002.

THOREAU, David Henry, Walden: A Fully Annotated Edition [1854], New Haven, Yale University Press, 2004.

TURNER, Frederick Jackson, "The Significance of the Frontier in American History" [1893] in Rereading Frederick Jackson Turner, New Haven, Yale University Press, 1998.

ANONYMOUS, “The New American Domesticated Male” in Life Magazine, January 4, 1954, 42-45. 


\section{NOTES}

1. For a comprehensive analysis of the developments of the idea of wilderness in American history, see Nash.

2. See in particular Annette Kolodny's seminal study of the gendered metaphors found in descriptions of the American landscape and their function in these many narratives presenting a lone white male protagonist travelling up and down an essentially feminine landscape described in erotic or maternal terms, a tradition which she describes as "America's oldest and most cherished fantasy: a daily reality of harmony between man and nature based on an experience of the land as essentially feminine-that is, not simply the land as mother, but the land as woman, the total female principle of gratification-enclosing the individual in an environment of receptivity, repose, and painless and integral satisfaction" (Kolodny, 4).

3. Natty Bumppo, James Fenimore Cooper's protagonist in The Last of the Mohicans (1826), was the first embodiment of this masculine ideal. He was a heroic frontiersman celebrated for his animal instincts and primitive manliness, a man who had to face Indians who moved like "wild beasts" and dressed up as a bear to infiltrate an Indian village. For Mark Twain, half a century later, the last real man in America was a little boy named Tom Sawyer who flees with wild child Huckleberry Finn and primitive black man Jim into the wild in search for adventures away from Aunt Polly's civilizing influence. In Jack London's The Call of the Wild (1903), the last real man in America is a dog who becomes a wolf, a revealing allegory of a passage from domestication to wildness. In Edgar Rice Burroughs' Tarzan of the Apes (1912), he is the orphan child of British aristocrats who is raised by African apes and eventually becomes "the killer of beasts and many black men" (Edgar R. Burroughs, 129). Varied in form and content, this literary archetype inevitably fed on an animal realm which offered a crucible for redemptive manly savagery and belligerence.

4. "The New American Domesticated Male" in Life Magazine, January 4, 1954, 42.

5. Those stories were published in pulp magazines like Male, Man to Man, Man's Magazine, Man's Life, Real Men, Real Action For Men, Man's Daring or Man's Illustrated to mention just a few of the more than 100 different magazines that were then available. Several of those had a circulation of more than one million, with True selling more than 2 million copies each month in the late fifties. Those "armpit slicks" or "sweats" as they were sometimes called, featured supposedly true stories about heroic men engaging in adventure, sport or hunting, as well as lurid reports on sexual matters. In a July 1964 issue of Writers' Digest, the editor of Argosy, one of the first magazines of the genre,encapsulates the desired style of this particular masculine trend in 1950s fiction: "We are principally interested in strong-action picture stories on non-war adventure themes; man against nature, man against beast, man against man. We try to stress the 'mantriumphant' idea whenever possible" (quoted in Parfray, 4).

6. These men's magazine were aimed at a working-class male audience that did not have much in common with the more cultivated, educated, wealthy, urban and refined readership of Playboy, founded in 1953, and which featured no stories like the ones in men's adventure magazines. Its founder, Hugh Hefner, remarked that men in adventure magazines spent most of their time "thrashing through thorny thickets or splashing about in fast flowing streams," but the Playboy readers were domesticated bachelors who "spend most of [their] time inside": "We like our apartment. We enjoy mixing up cocktails and an hors d'oeuvre or two, putting a little mood music on the phonograph, and inviting in a female acquaintance for a quiet discussion on Picasso, Nietzsche, jazz, sex" (quoted in Kimmel, 167). Despite being closer to the virile ethos of men's adventure magazines, Kerouac's work was never published in the latter whereas he often wrote short stories and articles for Playboy in the late fifties.

7. When quoted hereafter, The Dharma Bums and Desolation Angels will be referred to as DB and DA, followed by the page number. 
8. Although Kerouac's narrator and alter ego bears different names in the various novels that compose the Duluoz Legend-“Jack Duluoz" being the one he uses most (including in Desolation Angels) and Ray Smith the one he uses in The Dharma Bums, they all refer to his fictional persona as he insists in the preface to Visions of Cody: "Because of the objections of my early publishers I was not allowed to use the same personae names in each work. [...] In my old age I intend to collect all my work and re-insert my pantheon of uniform names, leave the long shelf full of books there, and die happy. The whole thing forms one enormous comedy, seen through the eyes of poor Ti Jean (me), otherwise known as Jack Duluoz" (Kerouac, 1993a, n.p.).

9. See for instance Phillips.

10. In her introduction to The Dharma Bums, Ann Douglas writes that Kerouac "could never write, as Snyder did, that 'the most / Revolutionary consciousness is to be found/ Among the most ruthlessly exploited classes: / Animals, trees, water, air, grasses.' Only people, or ghosts, can populate Kerouac's world" (DB, xxi). Though it is true that Kerouac does not share Gary Snyder's political commitment and environmental concerns, such a misreading of Kerouac's concern for animals shows the extent to which Beat scholarship has led a limited exploration of animals and animality, which in its turn, limits its understanding of Beat Generation writers.

11. Kerouac's fascination with London, Thoreau and Muir largely results from what he perceives to be their heroic manliness. In a letter to Gary Snyder from January 15, 1958, Kerouac voices his admiration in revealing terms: "I saw huge mountains in Greenland and dream'd of Thoreau, my boy, your boy Muir and my boy Thoreau... two of the same cloth... what men, what men" (Kerouac, 2000b, 122). After Japhy tells Ray about the harsh life that Muir led in the backwoods of the Sierra Nevada, the narrator responds in a similar fashion: "My goodness! He musta been tough!" (DB, 26).

12. I borrow the concepts of deterritorialization and reterritorialization from Gilles Deleuze's and Félix Guattari's Capitalism and Schizophrenia to describe the process of decontextualization and reactualization of the dominant gender relations in Kerouac's poetics; they adequately convey the constant play on cultural norms at work in Kerouac's novels, never quite transgressing nor entirely reproducing hegemonic forms of masculinity, a process which is paradigmatic of the "strange Anglo-American literature" according to the French philosophers: "from Thomas Hardy, from D.H. Lawrence to Malcolm Lowry, from Henry Miller to Allen Ginsberg and Jack Kerouac, men who know how to leave, to scramble the codes, to cause flows to circulate, to traverse the desert of the body without organs. They overcome a limit, they shatter a wall, the capitalist barrier. And of course they fail to complete the process, they never cease failing to do so. The neurotic impasse again closes-the daddy-mommy of oedipalization, America, the return to the native land-or else the perversion of the exotic territorialities, then drugs, alcohol-or worse still, an old fascist dream" (Deleuze and Guattari, 2004a, 144).

13. By "significant otherness" (and as opposed to "radical otherness"), I am referring to Donna Haraway's concept (which she uses to deconstruct human exceptionalism) in When Species Meet and The Companion Species Manifesto. Haraway argues that humans and domesticated animals are coevolved in complex and asymmetrical ways, something Kerouac hits upon in The Dharma Bums and Desolation Angels.

14. Though Kerouac's becoming-animal is thus founded, like Deleuze and Guattari's (partly influenced by their reading of Kerouac in that regard), on a binary distinction between wild and domestic, his vision of the wild as a garden and of wildlife as companion species differ markedly from that of the thinkers of "becoming-animal" who think that "anyone who like cats or dogs is a fool [con]" (Deleuze and Guattari, 2004b, 265). As Donna Haraway astutely remarks in When Species Meet, "D\&G's associational web of anomalous becoming-animal feeds off a series of primary dichotomies figured by the opposition between the wild and the domestic," most notably in their criticism of Freud's mistaking wolves for dogs in his analysis of the Wolf-Man, which, she writes, "is the first of a crow of oppositions [...] in A Thousand Plateaus, which taken 
together are a symptomatic morass for how not to take earthly animals-wild or domesticseriously" (Haraway, 2008, 28-29). In Kerouac's novels however, the flight from the domestic into the wild eventually results in a blurring of the domestic/wild dichotomy.

15. As Lawrence M. Hinman argues "There is an interesting symmetry in the relationship between courage and masculinity and the relationship between compassion and femininity in our society. Just as an absence of courage counts against a man's masculinity, so an absence of compassion often counts against a woman's femininity" (Hinman, 280). Kerouac's twist on gender norms is thus in keeping with his belief in Mahayana Buddhism, which "depicts wisdom as feminine and affective states, such as love and compassion, as masculine" (Cabezon, xi). Farther in the book, Cabezon adds that "We find in the scriptures of the Mahayana several instances in which wisdom is identified as female, and more specifically as mother (matr), whereas the less analytic and more emotive states that constitute 'method,' namely love (maitri), compassion, altruism (bodhicitta), and so forth, are identified with the male or "father" (pitr)" (183).

16. Of course, I do not mean to imply here that bugs are conscious of their own death, but to underline instead that the animal / human barrier has often been justified by men's consciousness of death (and thereby legitimating a long history of violence against animals), something Derrida seriously questions in his criticism of Heidegger's claim that only humans and the Dasein can access death as such: "animals have a very significant relation to death, [...] even if they have neither a relation to death nor to the 'name' of death as such [...]. But neither does man, that is precisely the point!" (Derrida, 1993, 76).

17. In The Beast and the Sovereign, Derrida remarks how bestiality-bestialité-and stupidity-bêtise -can be applied to humans only: "The adjective, epithet, attribute bête, or 'bestial' are never appropriate for animal or beast. Bêtise is proper to man" (Derrida,2009, 68). Deleuze makes a similar argument in Difference and Repetition: "Stupidity [bêtise] is not animality. The animal is protected by specific forms which prevent it from being 'stupid' [bête]" (Deleuze, 1994, 188).

18. In "The Animal That Therefore I Am," Derrida also answers Bentham's question positively, hereby denouncing the war between species that the othering of animals has engendered: "the response to the question 'can they suffer?' leaves no doubt. In fact it has never left any room for doubt; that is why the experience that we have of it is not even indubitable; it precedes the indubitable, it is older than it. No doubt either, then, for the possibility of our giving vent to a surge of compassion, even if it is then misunderstood, repressed, or denied, held in respect. Before the undeniable of this response (yes, they suffer, like us who suffer for them and with them), before this response that precedes all other questions, the problematic changes ground and base. [...] The two centuries I have been referring to somewhat approximately in order to situate the present in terms of this tradition have been those of an unequal struggle, a war being waged, the unequal forces of which could one day be reversed, between those who violate not only animal life but even and also this sentiment of compassion and, on the other hand, those who appeal to an irrefutable testimony to this pity" (Derrida, 2002a, 369).

19. It is precisely this radical alternative between two opposite poles of masculine identity that Homi Bhabha tackles in "Are you a man or a mouse?", in which he recalls his father insistently asking him this question when he was a boy. For the postcolonial studies scholar that he has become, it betrays the ambivalent nature of masculinity itself in its need to compulsively mark out bonding and exclusion. Like Kerouac, Bhabha remembers "thinking, in anxious awkwardness, caught impossibly, ambivalently, in between two different creeds and two different outlooks on life." Unlike Kerouac however, Bhabha goes beyond this feeling of duality, realizing that his answer to his father should have been "why do you keep asking me if I'm the mouse-man when you are rather like Freud's Rat Man?" (Bhabha in Berger, 58-59).

20. "Speciesism," a term coined by British psychologist Richard D. Ryder in 1970 and popularized by Australian philosopher Peter Singer in Animal Liberation (1975), refers to the widely held belief that the human species is inherently superior to other species and so has rights or privileges that 
are denied to other sentient animals. Speciesist arguments tend to overlook both the numerous similarities that exist between humans and animals and the various differences that exist between animals themselves. This conceptual simplification, which Derrida labels "stupid, theoretically ridiculous and violent" (Derrida, 2002b), often justifies and results in the violent treatment, abuse and exploitation of animals.

21. Coleridge already remarked that such traps were "foul breach of the rites of hospitality" meant "to assassinate [his] too credulous guests" (Coleridge, 322).

22. As "a primary male undertaking and a source of masculine identity through human history," hunting has provided American writers with many stories relating the dangers of the wild, showing the hunter as a bold and intrepid hero-or as David Leverenz would put it, as another embodiment of "the last real man in America" (Leverenz, 21). There is indeed a "long tradition in American fiction" which "uses hunting as the primary vehicle for a young man's journey or initiation to prove his manhood" (Carroll, 220-21).Bear hunting has always been a regular fixture in American fiction; see for instance "The Bear" in William Faulkner's Go Down, Moses, in which the bear hunt becomes an allegory for the young protagonist's coming-of-age. In Norman Mailer's Why Are We in Vietnam?, the young protagonist is on a grizzly hunting trip in Alaska with his father who, in his eyes, resorts to un-masculine hunting techniques including the use of a helicopter.

23. The authors of Animals and Women draw a direct connection between the violence inherent to hunting and masculine identity construction: "In the process of killing the animal, the hunter (re)establishes his secondary identity, that is, his masculine self. It is, in reality, the mental construct of masculinity that is fed by violence and death" (Adams and Donovan, 108).

24. This criticism also targets war in general, another activity in which men have had the opportunity to test and demonstrate their manliness, opposing men to other men instead of wild animals. Like the hunter, the soldier stands as an archetypal embodiment of warrior masculinity. Men's adventure magazines were actually replete with war stories about heroic soldiers and their glorious feats, with descriptions of aestheticized representations of violence. Alone in the wilderness of the Oregon forest, with the sole company of bugs and mice, Duluoz is led to ponder over the horrors of war, in which he sees another sign of "the foolishness of men": "somewhere men are fighting with frighting carbines, their chests crisscrossed with ammo, their belts weighed down with grenades, thirsty, tired, hungry, scared, insaned" (DA, 63). In Kerouac's holistic vision of the world, men and animals are "fellow creatures" which shall not kill.

25. Elsewhere in Kerouac's Legend, the animal does respond. In a short story he wrote while in Mexico in 1951, Kerouac describes the only confrontation between man and animal in his autobiographical cycle, on the occasion of a bullfight. Faced with this most bestial and dehumanizing spectacle, Kerouac humanizes the bull, providing him with thoughts and words of its own-"O why can't I go home?"-and describing him "looking up with human surprise at the sky and the sun" (Kerouac, 2000a, 36), in a reversal of the animal/human dichotomy. Instead of staging the wild animal as radical other in a tradition that goes from Aristotle (and the definition of "man as a thinking animal") to Lacan (who denies animals access to the symbolic for they have no language), Kerouac blurs the distinction. Beyond language and thought, it is their common experience of suffering that ties them together.

26. As Elizabeth Kolodny astutely remarks in her analysis of the pastoral impulse in American literature, "[o]ur continuing fascination with the lone male in the wilderness, and our literary heritage of essentially adolescent, presexual pastoral heroes, suggest that we have yet to come with a satisfying model for mature masculinity on this continent" (Kolodny, 147). More than thirty years after Kolodny's statement, the success of Jon Krakauer's Into the Wild (and Sean Penn's subsequent movie adaptation), in which the young male hero gives his savings to a charity and hitchhikes to Alaska to live in the wilderness, eventually having a close encounter with a 
bear, is a revealing example of the contemporary potency of this motif in the American imagination.

27. Gary Snyder's poetry also testifies to his fascination with bears as benevolent maternal figures, either celebrating Smokey the Bear-the mascot of the US Forest Service which he depicts as the reincarnation of Vairocana Buddha -in "Smokey the Bear Sutra," or else in "A Berry Feast"-the title of which is already an ironic twist on the popular image of the bear as a fiery beast, a poem Kerouac refers to in The Dharma Bums, mentioning Japhy's "tender lyrical lines like the ones about bears eating berries, showing his love of animals" (9).

28. In Sacred Tensions, Raymond L. M. Lee and Susan Ellen Ackerman underline the "gender transformation" of the deity of compassion in Buddhism. Avalokitesvara, a deity that dedicated his life to the salvation of others, was originally depicted as male in Indian Buddhism and later imagined in feminine terms when it was domesticated in China under the Tang and Sung dynasties: "The quality of compassion that Avalokitesvara represents [...] was conceptualized in feminine terms by the Chinese. They gradually feminized Avalokitesvara, who is portrayed in Indian Buddhism as unmistakably male. In China, until the tenth century, Avalokitesvara was represented in masculine form" (Lee and Ackerman, 69). This gender transformation accounts for its being often depicted with androgynous traits as Patricia Monaghan remarks in Goddesses in World Culture: "Described as androgynous in presentation and mannerism, Avalokitesvara is portrayed in many early statues and drawings in effeminate, though still masculine, form. He also possessed decidedly maternal propensities to protect the weak, heal the sick, and assist in matters of pregnancy and childbirth" (Monaghan, 131).

29. One of the most popular authors in American literature, Kerouac is also one of its most misrepresented practitioners, notably as a "wild rebel," an "enfant terrible" of American letters. In particular, his novels have often been misread as praises for savagery, barbarism and bestiality, most notably by Norman Podhoretz in his virulent condemnation of the Beats in which he sees "a close connection between [the Beat Generation's] ideologies of primitivistic vitalism and a willingness to look upon cruelty and blood-letting with complacency, if not downright enthusiasm," adding that "the spirit of [...] the Beat Generation strikes me as the same spirit which animates the young savages in leather jackets who have been running amuck in the last few years with their switch-blades and zip guns" (Podhoretz, 156).

30. Kerouac will devote a short text to his cat in the November 1959 issue of Escapade, "My Cat Tyke," later republished in Good Blonde and Others (1993).

\section{ABSTRACTS}

Throughout his autobiographical cycle of fourteen novels, Jack Kerouac tried to present his narrator and his protagonists as archetypes of American masculinity who fought against their perceived domestication in a society which they characterized as undergoing feminization. Whether it be in the Sierra Nevada in 1955, in The Dharma Bums (1958),or in the Northern Cascades in 1956, in Desolation Angels (1965), Kerouac's alter ego and first-person narrator engages in an escapist fantasy into the animal realm where he can regain a sense of authentic masculine identity, away from the feminizing effects of domesticity and civilization. Yet, large wild animals are almost never to be found in his novels and the long-awaited encounter with deadly predators does not occur, forcing the narrator to reconfigure the relationship between masculinity and animality. Taking the popular hunting narratives featured in men's adventure magazines as the 
dominant norm in this regard, this paper aims at showing how Kerouac's representation of masculinity and animality strongly diverges from the erotics of male predation to be found in the "real man VS wild beast" plot. In those two novels, his poetics revolves instead around notions of kinship and sentimentality towards smaller animals, transforming the manly ethos and the inhospitable wilderness of adventure stories of the times into a domestic world of mutual harmony and hospitality.

Tout au long de son cycle autobiographique de quatorze romans, Jack Kerouac présente son narrateur et les protagonistes de ses récits comme des archétypes de la masculinité américaine engagés dans une lutte contre leur domestication supposée dans une société qu'ils jugent en voie de féminisation. Que ce soit dans la Sierra Nevada en 1955, dans The Dharma Bums (1958), ou dans les Northern Cascades en 1956, dans Desolation Angels (1965), l'alter-ego et narrateur à la première personne de Kerouac se lance dans une fuite dans un monde animal fantasmé afin de reconquérir une identité masculine authentique loin de l'influence efféminante de la vie civilisée. Cependant, les grands animaux sauvages du continent américain sont presque totalement absents de ses romans, et la confrontation tant attendue avec de dangereux prédateurs n'arrive jamais, obligeant le narrateur à reformuler la relation entre masculinité et animalité. En prenant les récits de chasse des men's adventure magazines si populaire auprès du lectorat masculin des années cinquante comme la norme à cet égard, cet article montre comment la représentation de la masculinité et de l'animalité chez Kerouac diverge sensiblement de l'érotisme viril et prédateur qui caractérise les récits de confrontation entre hommes et animaux sauvages. Dans ces deux romans, sa poétique est au contraire fondée dans un sentiment de parenté et de compassion envers les animaux les plus insignifiants, transformant ainsi l'idéal de manliness et la nature sauvage et inhospitalière des récits d'aventure de l'époque en un monde domestique fait d'hospitalité et d'harmonie réciproque.

\section{INDEX}

Mots-clés: animaux, chasse, Desolation Angels, domesticité, écopoétique, féminisation, hospitalité, Jack Kerouac, masculinité, nature sauvage, roman d'aventure américain, The Dharma Bums

Keywords: American adventure fiction, animals, Desolation Angels, domesticity, ecopoetics, feminization, hospitality, hunting, Jack Kerouac, masculinity, The Dharma Bums, wilderness

\section{AUTHOR}

\section{PIERRE-ANTOINE PELLERIN}

Université de la Sorbonne Nouvelle - Paris 3 